\title{
Discussing the motives to learn Russian as a foreign language during COVID-19 pandemic: psychopedagogical aspect
}

\section{Acerca de los asuntos relacionados con los motivos de aprendizaje del idioma ruso como lengua extranjera en el contexto de COVID: aspecto psicológico y pedagógico}

\author{
Nazartseva Ekaterina \\ Peoples' Friendship University of Russia (RUDN University), Moscow, Russian \\ Federation \\ ORCID ID: https://orcid.org/0000-0001-5466-4863 \\ Fomina Lyudmila
}

The Russian Presidential Academy of National Economy and Public Administration, Moscow, Russian Federation

ORCID ID: https://orcid.org/0000-0001-9309-4736

Bodrova Tatyana

Peoples' Friendship University of Russia (RUDN University), Moscow, Russian Federation

ORCID ID: https://orcid.org/0000-0001-7049-7452

Received 10-10-20 Revised 11-12-20 Accepted 01-13-21 On line 01-14-21

*Correspondence

Email: olfiss@list.ru
Cite as:

Nazartseva, E., Fomina, L., \& Bodrova, T. (2021) Discussing the motives to learn Russian as a foreign language during COVID-19 pandemic: psychopedagogical aspect. Propósitos y Representaciones, 9 (SPE1), e868. Doi: http://dx.doi.org/10.20511/pyr2021.v9nSPE1.868 


\section{Summary}

The article shows that the coronavirus pandemic has led to a rapid modernization of Russian education due to the widespread introduction of online learning. The features of the modern educational environment are considered, its advantages and disadvantages are analyzed. It is proved that psychologists and teachers should pay special attention to the study of the motives of learning Russian as a foreign language at the pre-university stage of training. Maintaining motivation will contribute to the success of training, maintaining the prestige of Russian education and, as a result, attracting foreign applicants and students to study in Russian universities.

Keywords: educational environment, motives, Russian as a foreign language.

\section{Resumen}

En el artículo se describe como la pandemia de coronavirus ha exigido una rápida modernización del sistema educacional ruso introduciendo de forma generalizada la enseñanza en línea. Se analizan las particularidades del entorno educativo moderno, se examinan sus ventajas y desventajas. Se ha demostrado que los psicólogos y profesores deben brindar especial interés al estudio de la motivación del aprendizaje del idioma ruso como lengua extranjera en la etapa de educación preuniversitaria. Apoyar la motivación contribuirá al éxito de la enseñanza, manteniendo el prestigio de la educación rusa y, como resultado, atrayendo a candidatos y estudiantes extranjeros para que estudien en universidades rusas.

Palabras clave: entorno educativo, motivación, idioma ruso como lengua extranjera.

\section{Introduction}

The spread of the coronavirus pandemic around the world affects many areas of human life. One of these areas is the higher education system. The pandemic has led to a significant change in the system of the global education market that has been built for decades.

COVID-19 has put universities in difficult conditions, forcing them to adapt to the current events as soon as possible. The pandemic has a negative impact on the maintenance of international cooperation in the field of education: many programs, including exchange and academic mobility programs, have been suspended. The COVID-19 pandemic has accelerated digitalization and transition to online learning. Most Russian universities are faced with the task of providing an educational process for foreign students who are forced to stay in their country during the pandemic or go home.

The most vulnerable segment of education was associated with pre-university training of foreign students. Pre-university education for foreign students turned out to be the most vulnerable segment of education. It is also clear that if online education does not work and shows low effectiveness in few years, the number of foreign students in Russian universities will decrease significantly.

Russian universities have to deal with sensitive issues such as the appropriate forms of online education; necessary technical equipment; the criteria for assessment of training effect; the way of enrolling foreign students; the methods of motivating foreign students to learn Russian as a foreign language.

\section{Level of knowledge}

The analysis demonstrates that the problems of motivation have been studied since early XX century. However, each age has new factors influencing a person's motivational abilities.

A.G. Asmolov (1989), I.R. Altunina (2005), L.V. Borozdina (2012), E.V. Gorchakova (2020), V.A. Ivannikov (2006), G.V. Litvinova (2003), A.B. Orlov (1979), P.V. Simonov (1987) and many other scholars made a significant contribution to study of a person's motivational aspect. 
L.I. Bozhovich (1978), A.K. Markova (1983), A.A. Rean, Ya.L. Kolominsky (2000) devoted their studies to the issue of a person's motivational aspect in professional and educational activities.

B.S. Bratus (2007), C.P. Korolenko, T.A. Donskikh (1990) and other researchers studied potential (normative) motivation.

I.R. Altunina (2005), A.I. Vysotsky (1979), I.Yu. Kulagina (2011), N.N. Rubtsova, T.G. Ivashina (2002) and others covered motivation of social behavior in their works.

The researchers prove that personal motivational sphere is a basis for development of interpersonal relationships. The original term was social behavior. I.R. Altunina defines it as "a certain psychological impact on people, the processes occuring in the society, and on a person's position in the system of human relationships" (Altunina 2005, p. 74-75).

V.V. Rubtsov \& T.G Ivashina identifies social (motivating) motives as a separate group of motives. She believes that this group of motives can be attributed to the leading ones. They are determined by a separate independent human need, which is a hierarchical structure that represents the motivational-need basis of communication. Further development of the theory of social need is presented in the works of L.I. Marisova. In her opinion, the structure of social needs highlights the need to belong to a social group, the need for empathy and empathy, the need for a loved one and the presence of relationships with him, the need for support by other people, the need to help other people, the need to exchange opinions, the need for a common understanding of the world around, the need for evaluation by other people.

Traditionally, the basic social motives include motivation of affiliate and motive of achievement of success. The motive is considered as a special case of motivation, which is limited by the state of the subject, time and situation.

Also, Russian scientists have conducted quite a few experimental studies of the motives of social behavior of participants in the educational process and the influence of motivation on aspects of educational activity.

Ya.O. Mikfeld proves that the motives to achieve success are crucial, they "equally influence success in any activity, including educational activity focused on forming writing skills" (Mikfeld 2004, p. 5).

\section{Problem statement}

Foreign students who start learning Russian as a foreign language are unable to get involved into the Russian language environment due to COVID-19 restrictions. Closed borders made foreigners get language training within their home country.

Under these circumstances there arises the need to study motivational factors. Study of motivation has a practical use, as it will help to organize educational process in such a way which would mainstream the students' cognitive potential.

\section{Discussion}

\section{The new educational environment as the realities of modern education}

Russian education is part of the global educational space, which under the conditions of coronavirus infection is experiencing a strong transformation. However, despite all the global upheavals, the main goal of the state's educational policy remains unshakable: "creating conditions for ensuring high-quality training of graduates while maintaining the fundamental nature of higher education and its compliance with the current and future needs of the individual, the labor market, society and the state" (Baidenko, 2020, p.5). The main strategic goals and objectives of modernization of education are reflected in the doctrine of education of the Russian Federation until 2025, in the Federal State Standards of Higher Professional Education.

The main objectives of vocational education are:

1) training a competitive qualified specialist; 
2) training a competent specialist who is capable of effective work in accordance with the chosen specialty;

3) training a specialist, ready to a career development. education.

The new format of online learning leads to the need to rethink existing traditions in

Online learning as a relatively new method of learning is a major feature of the new educational environment. It cannot be considered as a complete replacement for traditional education.

The goal of online learning is to achieve a high level of competence. Unlike traditional, online learning is more focused on independent work of students, but with the support of a teacher.

Online learning offers new opportunities. The advantages of the new educational environment include:

- availability;

- modularity;

- training at workplace;

- progress;

- manageability.

The disadvantages of online learning include:

- costly technical equipment;

- lack of computer literacy;

- risks of equipment failure and the Internet operation failure;

- isolation of the teacher and students;

- restrictions for certain types of classes and subjects;

- need for a good planning;

- need for constant technical support.

The existing experience of organizing the educational process shows that online learning is a complex system. The desire of foreign students to continue their studies in Russian universities depends on the quality of the organization of the educational process.

Consider the concerns which arise with the creation of educational space in the online education system:

1) students from many countries have no technical equipment and extended network coverage, e.g. foreign students from Latin America and African countries.

2) many students consider online format to be appropriate for creating language environment, which is an inadequate replacement of traditional education;

3 ) as online education lacks working educational control systems, it results in lower quality of education.

4) there may be failures of online applications used for remote lessons (lectures and seminars).

5) teaching staff may lack proficiency in online training.

Socially disadvantaged students found themselves under the most difficult conditions. Many students, especially from rural regions, cannot join the classes according to the schedule.

\section{Results of the survey}

As mentioned above, the most important task facing universities at the present stage is to create the necessary conditions for online learning. In order to use all the levers of educational process management at the stage of pre-university training of foreign students, it is necessary to have an idea of the motives of studying the Russian language of foreign students.

To that end, N.A. Emelyanova's "Motives to learn a foreign language" (2017) survey was carried out.

\section{Participants of the survey}

157 foreign students from RUDN University, who study online, took part in the survey. The age range of the students was from 17 to 27 . The sample was random. 
The survey was conducted in the November-December of 2020.

The results were united in 8 thematic groups with the single value dominant.

\section{Results of the survey}

Let's present the test results in the form of the following diagram:

\section{Figure 1. Motives to learn Russian as a foreign language}

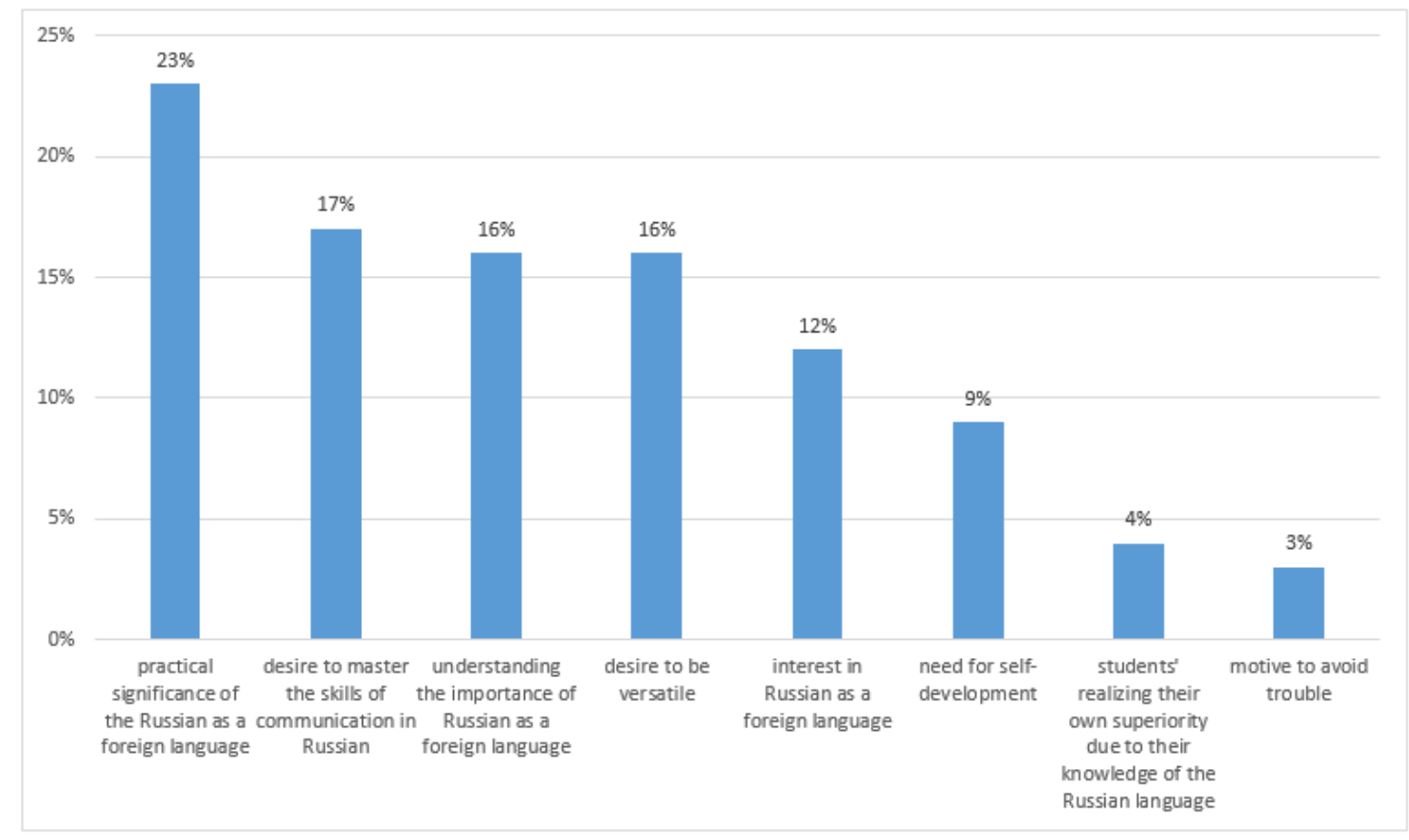

The study showed that the practical significance of the Russian as a foreign language dominates among foreigners. Foreign students associate the importance of the Russian language with future work, study, as well as with the prospects that open up to a person learning a foreign language. Foreigners enter the preparatory department with the exact goal of continuing their study in Russian universities. society.

The practical significance of learning Russian will make it possible to become useful to

Many foreign students relate Russian to fulfilling their dreams linked to working abroad.

The increasing importance of the Russian language to the world community is among the motivators of the audience. By learning a foreign language, students learn a lot of new things, better understand their native language.

The second most important place is occupied by the motives associated with the desire to master the skills of communication in Russian. The study shows that knowledge of the Russian language increases the opportunities to communicate.

Knowledge of Russian expands the students' social circle, provides communication with their foreign friends and between each other. The skill of speaking Russian is of special significance, related to the prospects of getting education in Russian.

The motive to master Russian speaking skills is explained by the fact that foreign students like communicating in everyday life and at university in Russian as lingua franca.

The third place is for understanding the importance of Russian as a foreign language, which includes social usefulness, the opportunity to get higher education and become a highquality specialist, and the opportunity to work in Russia.

For instance, naming the motives for learning the Russian language, foreign students note "I want to be useful for society", "With higher education I can be useful for society". 
The objective significance of the Russian language for foreign students is somehow connected with the planning of their future career. The Russian language moves from the group of socially significant factors to the group of personally significant ones.

The objective importance of Russian is related to the opportunity to get higher education in it. Foreign students highlight the following stimuli to learn Russian: "I need to learn Russian to get my higher education diploma", "All the professions I am interested in require knowledge of Russian", "First and foremost, it is higher education; to get it, I need to learn Russian".

Foreign students associate the importance of learning Russian with the opportunity of acquiring new special knowledge.

The Russian language is the key to success in professional activities ("with knowledge of Russian, I can find a better job"), the opportunity to visit foreign countries ("knowledge of the Russian language is a sure way to go on foreign business trips"). versatile.

The fourth place in importance is taken by the motives associated with the desire to be

Foreigners believe that without knowledge of foreign languages it is impossible to be a versatile and educated person. Knowledge of the Russian language enhances the general knowledge of a person. Foreigners think that knowledge of the Russian language is a necessary quality of a modern educated person.

The fifth motivator is the interest in Russian as a foreign language.

The interest in Russian is linked to learning languages ("Russian is one of the most interesting courses", "I like learning foreign languages", "I like learning Russian", "I like learn something new when learning Russian") and Russian linguistic culture ("I like to learn a language of other culture").

"The need for self-development" takes the sixth place in the system of motivation of foreign students.

Learning Russian contributes to the development of mental abilities, improves memory and allows the students to better learn other people and themselves.

The next (seventh) place is occupied by the students' realizing their own superiority due to their knowledge of the Russian language.

As the foreigners note, knowledge of the Russian language allows them to stand out from other people. The most frequent responses are the following: others";

- "The mastery of the Russian language is the most effective way to stand out from many

- "Knowledge of the Russian language is a point of pride before those who do not speak it";

"Let others see that with knowledge of the Russian language, I am much superior";

- "I am sure that it is more difficult to master the Russian language than any other subject, so I have more reasons to be proud of my achievements".

Knowledge of Russian allows a person to stand out and feel strong: "Learning Russian makes me feel stronger".

Knowledge of Russian allows a person to feel their own superiority, and knowledge of Russian is perceived as the envy: "The biggest pleasure is when other people envy my knowledge of Russian".

The eighth group of motivators is a group of qualities implying the desire for selfidentification with honorable people. Knowledge of Russian allows foreign students to relate themselves to respectable people. These are prominent people who know several foreign languages, book and film characters. The desire to be like Russian language professors is also a motivator to learn Russian.

The least important motive is the motive of avoiding trouble. This motive is the least productive. However, it also encourages learning Russian as a foreign language. There are second or third-generation Russian learners among preparatory department students. They say that "Learning Russian as a foreign language is a tradition of our family".

The foreigners named constructive factors which influence the desire to learn Russian: "If I have to learn Russian, I will do my best". 
The motive to avoid trouble is related to a non-independent decision to learn Russian: "My parents think that with knowledge of Russian I will have the best prospect".

Destructive factors that affect learning the Russian language are associated with the reluctance to learn it: "I have never liked the Russian language", "I don't know Russian and I don't care either".

The research shows that the value-important motives to learn Russian as a foreign language are: "practical importance of Russian as a foreign language" (23\%), "the desire to master communication skills in Russian" (17\%), "understanding the importance of Russian as a foreign language" (16\%), "the desire to be versatile" (16\%). They made up $72 \%$ of respondents' answers. They account for $72 \%$ of respondents' answers.

These motives for learning Russian as a foreign language are the most stable. They determine the desire of foreign students to learn Russian.

Peripheral areas include motives to "the interest in Russian as a foreign language" (12\%), "need for self-development" (9\%), "students' realizing their own superiority" (4\%).

The least important motive is "he motive to avoid trouble" (3\%).

\section{Conclusiones}

To summarize, the system of pre-university training of foreign students in the Russian Federation has undergone the strongest impact of the global pandemic. Despite the previous electronic resources, it has brought a lot of challenges, which include the problem of forming and maintaining foreign students' motivation to learn Russian as a foreign language.

The survey demonstrates that foreign students, who have chosen Russian universities for their study under the circumstances of COVID-19 pandemic, have constructive motivation settings which would maintain interest to learn Russian and study in Russia. A relatively few number of students have destructive motivation settings; nonetheless, it is these settings that require professors' and methodologists' special attention. Destructive motivators may eventually decrease interest to study.

\section{References}

Altunina, I.R. (2005) Motive and motivation of social behavior in children: theory of development of motives and motivation of social behavior. Moscow, Russia, 226

Asmolov, A.G. (1989) Personality: psychological strategy of education. New pedagogical thinking. Moscow, Russia, 206-220

Baidenko, V.I. (2020) The Bologna Process: Structural Reform of Higher Education in Europe MISIS. Russian New University, Research Center for Quality Problems of Training Specialists, 128

Borozdina, L.V. (2012) Diagnostics of motivation for achieving success and avoiding failure: a textbook for a special practice (author's development of a psychodiagnostic scheme). Moscow, Russia, 81

Bozhovich, L.I. (1978) Problems of personality formation in ontogenesis. Voprosy Psychologii. No 4, 23-35

Bratus, B. S. (2007) General psychology against the background of modernity. Bulletin of the Moscow University. Ser. 14. Psychology. No 3, 96-101

Emelyanova, N. A. (2017) Formation of optimal motivation for foreign language mastery by students of a non-linguistic university. PhD. thesis. Moscow, Russia, 229

Gorchakova, E.B. (2020) The motive for achieving success in the structure of the personality and activity of future managers. PhD. thesis. Khabarovsk, Russia,164

Ivannikov, V.A. (2006) Psychological mechanisms of volitional regulation: a textbook. St. Petersburg, Russia, 208

Korolenko, C. P. \& Donskikh, T.A. (1990) Seven paths to disaster. Destructive behavior in the modern world. Novosibirsk, Russia, 224 
Kulagina, I.Yu. (2011) The formation of motivation in the meta-situation level in adolescence. At the threshold of adulthood. Moscow, Russia, 77-85

Litvinova, G.V. (2003) The motive for achieving success as a factor of personal development (based on the example of younger schoolchildren and younger adolescents). PhD. thesis. Khabarovsk, Russia, 157

Markova, A.K. (1983) Activation of motivation to study in schoolchildren. Moscow, Russia, 16-26

Mikfeld, Ya.O. (2004) The influence of motives of social behavior on the formation of the written speech in younger schoolchildren. PhD. thesis. Moscow, Russia, 216

Orlov, A.B. (1979) Two orientations in the study of motivation abroad. Bulletin of Moscow State University. Ser. 14 Psychology. No 2, 17-20 Russia, 416

Rean, A.A. \& Kolominsky, Ya.L. (2000) Social pedagogical psychology. St. Petersburg,

Rubtsov, V.V. \& Ivashina T.G. (2002) Designing the development of educational environment at school. Moscow, Russia, 272

Shadrikov,V.D. (2003) Introduction to psychology: motivation of behavior. Moscow, Russia, 136

Simonov, P.V. (1987) The motivated brain. Moscow, Russia, 272

Vysotsky, A.I. (1979) Volitional activity of schoolchildren and methods of its study: a textbook. Chelyabinsk, Russia, 69

*The publication has been with the support of the "RUDN University Program 5-100". 